\title{
Does Sustainability Disclosure Valuable? Study on Issuers under the SRI-KEHATI Index of the Indonesia Stock Exchange
}

\author{
Budi Purwanto $^{1}$, Luthpiyah Juliandra ${ }^{2}$, Siti Jahroh ${ }^{3}$ \\ $\underline{\text { budipurwanto@apps.ipb.ac.id }{ }^{1}, \underline{\text { sitijahroh@gmail.com }}{ }^{2}, \underline{\text { Luthpiyah juliandara@apps.ipb.ac.id }} \text { \} }}$
}

Department of Management, IPB University ${ }^{1}$, School of Business, IPB University ${ }^{2,3}$

\begin{abstract}
Sustainability disclosures are intended to attract investors' attention, however, for issuers under the SRI-KEHATI Index, their fundamental performance does not better than under market performance in general. This study aims to analyze whether the disclosure of sustainability can create economic value added and market value. The sample is all issuers under the SRI-KEHATI index from the beginning to 2019 which are filtered based on reporting performance. Sustainability disclosure includes environmental, social and growth factors. The analysis was performed using a moderated fixed effects panel data regression model. The results show that the disclosure of sustainability does not have a direct effect on both market and economic value added, and does not strengthen or weaken the relationship between economic added and market value. This result implies that investors do not aware of the effect of sustainability disclosure on the fundamental performance and market value.
\end{abstract}

Keywords: Fundamental performance, Market performance, SRI-KEHATI Index, Sustainability disclosure.

\section{Introduction}

Environmental issues are becoming a hot issue nowadays. Consequently, the government, companies, and the community are required to work together to forestall environmental conditions from getting worse. Specifically, companies have a stake in environmental degradation that occurs, such as poor management of industrial waste, air pollution generating from plant operations, and many others. Accordingly, companies also need to participate in maintaining the quality of the surrounding environment. Companies' contribution to preserving the environment expect to be an added value for the environment, investors, and shareholders.

Companies disclose their contributions and works that promote environmental preservation through sustainability report disclosure intending to provide information to investors and other stakeholders [1-3]. Santis [4] 
mentioned that investors are willing to pay more for sustainable companies seeing that these companies adopt CSR policies, have transparent management, hold good governance, and less risk. The disclosure supposed to be able to predispose the perceptions of shareholders though the company has not yet implemented actual sustainability performance $[3,5,6]$. The gap between the reported disclosure and the actual activities companies did since the sustainability report not audited as it has done in the annual report $[3,7]$. Companies that have disclosed sustainability reports and acquire high scores indicate that these companies have a better contribution to environmental preservation compared to other companies [3,5,8]. In Indonesia, the pioneer of sustainability investment in the capital market is SRI KEHATI. From 2010 to 2019 the SRI KEHATI stock price index was higher than the LQ45 stock price index. Whereas companies incorporated in LQ45 have a high level of liquidity and a large market capitalization.

Present-day stakeholders are more attentive to the role of companies in advancing potential strategies of corporate sustainability through environment improvement programs [10]. Environmental sustainability becomes a primary indication of current and also future performances as an integration environmental sustainability accompanied by products and services that are environmentally friendly shall increase market valuation and the company's competitive ability [10-13]. Hence, according to Connelly [14] and Papoutsi [3], companies are willing to spend more resources. Notably, those identified with corporate sustainability that is not observable easily by stakeholders and shareholders for activities related to preservation are not measurable such as earnings or equity $[3,14,15]$.

Companies will be able to refine their image by publishing sustainability reports. This action could be one of the benefits of the company. Furthermore, companies that contribute significantly to environmental preservation would create new product and service innovations so that companies could create new market shares. Nevertheless, there are weaknesses of the impact of the company's contribution to environmental preservation on the company's value, namely "It Pays to be Green" or "It costs to be Green" as explained by Trump and Guether [16].

Companies can refer to the Global Reporting Initiative (GRI) guidelines to understand sustainable reporting standards even though these standards have widely criticized. The criticism itself intended to advance the development of sustainability within the organization and build the company's sustainability performance more accountable and transparent [17-19]. As well, to render GRI to be the most relevant sustainability report standard [20,21]. Up to now, numerous organizations or companies that have issued sustainability reports. 
Researches related to sustainability reports have also escalated [19],[22]. These studies, among others: the determination of internal and external factors that are the primary keys to adopting sustainability performance reporting [22], the relationship between sustainability reporting and organizational performance $[23,24]$, and the quality of sustainability reporting [25].

Investors appreciate companies that have contributed to preserving the environment by disclosing sustainability reports. The disclosure even has a positive impact on share prices [26]. That statement is different from the explanation of Guidry and Patten [27] whose mentioned that sustainability reports disclosure does not affect the market reaction. Du et al's [28] study found that markets react positively but only in the short term. The disclosure of the sustainability report itself does not affect the company's performance [29] because many factors can affect the level of company performance. Based on the description above, the purpose of this study is to determine the ability of sustainability report disclosure in influencing market performance.

\section{Literature Review}

Sustainability is a primary concept in environmental management. This concept may not straightforward as to conceptualize various living things and their surroundings nature[16]. Sustainable performance requires a framework to connect environmental and social management to business. Subsequently, integrate both environment and social information along with economicbusiness information [30]. Effective sustainability performance is expected to increase company profitability. Still, social responsibility costs money that could worsen company performance [31]. Jensen [32] also stated that environmental and social responsibility possible to confine a company to maximize its corporate value and be the cause of poor company performance. Companies that contribute to environmental preservation could influence investors to invest in them. However, not all investors have the same thought in this matter. Only a few investors interested to invest in companies that care about the environment. Those investors' investments are also finite to particular times and the level of investor's experiences [27,33]. That knowledge supports findings that the disclosure of such information has only a small impact on investment decisions [27].

Disclosure of sustainability reporting leads to an impression of an ethical corporate image that cares for the environment and could become a competitive advantage for the company compared to other companies [27]. Financial performance has nothing to do with the disclosure of sustainability reports since 
the corporate finance will increase as the goods and services sales of the company increase. People buy goods or services according to their level of needs. In that case, companies may become required to be more eagerly in branding their products to be environmentally friendly products or services. If the company determines to invent products or services that are more environmentally friendly, the company needs conscientious planning to ensure the costs incurred can improve the company's revenue. Reliable financial performance will be a signal for investors. However, under a rapidly changing competition situation making fundamental performance less attractive to investors. Tortella and Brusco [34] stated that the fundamental performance of the company did not affect market performance.

\section{Method}

This study uses quantitative data available in the company's annual report from 2013-2018. The population in this study is companies listed on the "SRIKEHATI" Index. The "SRI-KEHATI" Index is a pioneer of sustainable investment in Indonesia through the capital market. The purpose of this index is to encourage investors to be more concerned about the environment (environmentally friendly) refers to the basic concept of sustainable development. Thus, all members of the companies that incorporated in the "SRIKEHATI" index shall publish Sustainability Report.

The variables in this study consist of two independent variables (sustainability report (SR) and fundamental performance) and one dependent variable (market performance). Fundamental performance is proxied by Economic Value Added (EVA), while market performance is proxied by Market Value Added (MVA). The sustainability report contains three measurement factors, namely economic performance, social performance, and environmental performance. These three factors are measured by the Sustainability Report Disclosure Index (SRDI) following G4 guidelines. The total indicators of each economic, social, and environmental performance are 9, 38, and 34. "1" score given if the company discloses to the public. "0" score given if the company does not disclose to the public. The more indicators published, the higher the score obtained by the company.

Positive EVA value indicates that the company can create wealth value from the capital. Also, the company can provide added value from the spending capital. Companies with a positive MVA value means the company can increase value for the company. The next step is testing the hypothesis between the dependent and independent variables using panel data regression to answering 
Hypothesis 1 and Hypothesis 2 (Equation 1). This research also uses the Panel Data Moderating Regression Analysis (MRA) method to find out whether the company's fundamental performance can strengthen or weaken the effect of sustainability reports with market performance (equation 2).

$$
\begin{aligned}
& M V A_{i t}=\alpha+\beta_{1} S R_{i t}+\beta_{2} E V A_{i t}+e_{i t} \\
& M V A_{i t}=\alpha+\beta_{1} S R_{i t}+\beta_{2} E V A_{i t}+\beta_{3} S R_{i t} E V A_{i t}+e_{i t}
\end{aligned}
$$

Where MVA is Market Value Added, $\alpha$ is a constant, $\beta$ is coefficient of each variable, SR is a sustainability report variable, EVA is the Economic Value Added of company $i$ in year $t$. The hypothesis of equation 1 is as follows:

$\mathrm{H}_{01}=\mathrm{SR}$ has a significant positive effect on MVA

$\mathrm{H}_{11}=\mathrm{SR}$ has no significant positive effect on MVA

$\mathrm{H}_{02}=$ EVA has a significant positive effect on MVA

$\mathrm{H}_{12}=$ EVA has no significant positive effect on MVA

$\mathrm{H}_{03}=$ EVA strengthens the effect of SR on MVA

$\mathrm{H}_{13}=$ EVA does not strengthen the influence of SR on MVA

\section{Result}

There are 21 companies listed in the Sri Kehati Index. All of these companies have disclosed sustainability reports. However, not all companies publish regularly annually (Table 1). An average, 5 (five) companies per year not published their sustainability reports. The year with the most number of companies not publishing their sustainability reports was 2018, which was eight companies. The company that most often did not publish its sustainability reports was BSDE, which was 5 (five) times in the period of research. BSDE only published its sustainability reports once in 2014 . Two companies published their sustainability reports 2 (two) times during the research period, namely INDF and WSKT. INDF company published sustainability reports in 2014 and 2015, while WSKT in 2013 and 2017. AALI company obtained a maximum on social performance three times and once on economic performance. BMRI company also received a maximum score on social performance in 2016. Apart from these two companies, there was no other company that achieves the maximum score.

Tabel 1. The number of companies that do not publish sustainability reports per year 


\begin{tabular}{lccc}
\hline Year & ECDI (Emiten) & SODI (Emiten) & ENDI (Emiten) \\
\hline 2013 & 5 & 5 & 5 \\
2014 & 5 & 5 & 5 \\
2015 & 4 & 4 & 4 \\
2016 & 4 & 5 & 5 \\
2017 & 2 & 2 & 4 \\
2018 & 8 & 8 & 8 \\
\hline
\end{tabular}

Companies that are indexed by "SRI-KEHATI" do not all gain added value from the capital that has spent. Since based on the results of EVA and MVA calculations, some companies possess negative values in EVA and MVA. The lowest EVA value found on WSKT company in 2018 of IDR-42.440 and the highest EVA owned by KLBF company in 2017 was IDR50 billion (Table 2). Yet, EVA in the "SRI-KEHATI" Index is IDR-898 billion, which means that averagely those companies have not been able to yield added value from the capital that has spent. The lowest MVA value is the BBNI company of IDR374.019 billion and the highest MVA of IDR537.495,5 from the TLKM company. The average MVA of the 21 companies is IDR82.654,1 billion. Positive results represent that companies in the "SRI-KEHATI" Index could increase the company's added value in terms of market performance.

Tabel 2. The description of EVAs and MVAs

\begin{tabular}{|l|c|c|}
\hline & $\begin{array}{c}\text { EVA } \\
\text { (IDR billion) }\end{array}$ & $\begin{array}{c}\text { MVA } \\
\text { (IDR billion) }\end{array}$ \\
\hline $\min$ & $-42.440,0$ & $-374.019,0$ \\
\hline $\max$ & 50,3 & $537.495,6$ \\
\hline mean & $-898,9$ & $82.654,1$ \\
\hline
\end{tabular}

The regression test resulted in Table 4 without using a moderating variable can be seen that the EcDI model has an error type 1. For this reason, the EcDI model cannot be concluded. While from the Sodi and EDI models it is seen that there are no variables that have a significant effect on market performance variables (Table 4) and were likely the results of hypotheses 1 and 2, namely reject $\mathrm{H}_{0}$ and accept $\mathrm{H}_{1}$. The EVA variable also acts as a moderating variable and the EcDI model has an error type I. Error type 1 is seen from the p-value of the intercept greater than 0.5 . In the moderating model, there are also no variables that have a significant effect on market performance. So the results of the third hypothesis are rejected $\mathrm{H} 0$ and accept $\mathrm{H}_{1}$ (Table 5). These results are 
by the hypothesis that was built. Also, the moderating model produced a greater p-value. The greater P-value indicated that the sustainability report variable and fundamental performance increasingly have not a significant impact on stock performance.

Simultaneously, the SR and EVA variables did not affect the MVA variable. $\mathrm{R}$ square of variables with and without additional moderating variables was not too different. These results show that the model without moderating is better than the moderating variable.

Tabel 3 The results of panel data regression with the random effect model

\begin{tabular}{|c|c|c|c|c|}
\hline Variable & Estimate & $\operatorname{Pr}(>|z|)$ & R-square & P-value \\
\hline \multicolumn{5}{|c|}{ MVA=f(EcDI, EVA) } \\
\hline (Intercept) & $5,86 \mathrm{E}+04$ & 0,09401 & \multirow{3}{*}{0,055161} & \multirow{3}{*}{0,027585} \\
\hline EcDi & $6,02 \mathrm{E}+04$ & $0,00754 * *$ & & \\
\hline EVA & $4,42 \mathrm{E}-04$ & 0,7555 & & \\
\hline \multicolumn{5}{|c|}{$\mathrm{MVA}=\mathrm{f}(\mathrm{SoDI}, \mathrm{EVA})$} \\
\hline (Intercept) & $7,32 \mathrm{E}+08$ & $0,03428 *$ & \multirow{3}{*}{0,015047} & \multirow{3}{*}{0,39081} \\
\hline SoDI & $3,25 \mathrm{E}+08$ & 0,17517 & & \\
\hline EVA & $3,30 \mathrm{E}+00$ & 0,82018 & & \\
\hline \multicolumn{5}{|c|}{$\mathrm{MVA}=\mathrm{f}(\mathrm{EnDI}, \mathrm{EVA})$} \\
\hline (Intercept) & $7,70 \mathrm{E}+04$ & $0,02579 *$ & & \\
\hline EnDI & $3,16 \mathrm{E}+04$ & 0,39413 & 0,0061973 & 0,68147 \\
\hline EVA & $2,93 \mathrm{E}-04$ & 0,84074 & & \\
\hline
\end{tabular}

Tabel 4 The results of data panel moderating regression analysis with the effect model

\begin{tabular}{|c|c|c|c|c|}
\hline Variable & Estimate & $\operatorname{Pr}(>|z|)$ & R square & P-value \\
\hline \multicolumn{5}{|c|}{$\mathrm{MVA}=\mathrm{f}\left(\mathrm{EcDI}, \mathrm{EVA}, \mathrm{EcDI}{ }^{*} \mathrm{EVA}\right)$} \\
\hline (Intercept) & $5,72 \mathrm{E}+04$ & $0, .108606$ & \multirow{4}{*}{0,058368} & \multirow{4}{*}{0,055979} \\
\hline EcDi & $6,37 \mathrm{E}+04$ & $0,006103 * *$ & & \\
\hline EVA & $2,40 \mathrm{E}-05$ & 0,987783 & & \\
\hline EcDi*EVA & $1,88 \mathrm{E}-03$ & 0,533832 & & \\
\hline \multicolumn{5}{|c|}{ MVA=f(SoDI, EVA, SoDI*EVA) } \\
\hline (Intercept) & $7,31 \mathrm{E}+04$ & $0,03749 *$ & \multirow{4}{*}{0,015172} & \multirow{4}{*}{0,59779} \\
\hline SoDI & $3,27 \mathrm{E}+04$ & 0,17527 & & \\
\hline EVA & $2,70 \mathrm{E}-04$ & 0,86655 & & \\
\hline SoDI*EVA & 7,07E-04 & 0,9338 & & \\
\hline \multicolumn{5}{|c|}{$\mathrm{MVA}=\mathrm{f}(\mathrm{EnDI}, \mathrm{EVA}, \mathrm{EnDI} * \mathrm{EVA})$} \\
\hline (Intercept) & $7.70 \mathrm{E}+04$ & $0,02837^{*}$ & \multirow{2}{*}{0,0062286} & \multirow{2}{*}{0,8579} \\
\hline EnDI & $3.17 \mathrm{E}+04$ & 0,39504 & & \\
\hline
\end{tabular}




\begin{tabular}{|c|c|c|}
\hline EVA & $2.70 \mathrm{E}-04$ & 0,86677 \\
\hline EnDI*EVA & $6.77 \mathrm{E}-04$ & 0,9764 \\
\hline
\end{tabular}

\section{Discussions}

Based on the study results, apparently that companies indexed by "SRIKEHATI" were unable to raise the added value from the applied capital. This finding was a lesson for companies both to upgrade their capital structure and counted managers to act as shareholders where they can select investments that maximized returns and minimized capital costs. The market performance of the "SRI-KEHATI" indexed company was adequate to establish added value for shareholders. The research results denoted that SR not consequent on market performance by following researches from Muallifin and Priya [35]. This insignificant influence implied that sustainability has not been able to impress investors to assign investment decisions in the capital market. The findings also revealed that the company's performance did not affect market performance. This fact elucidated that investors did not invest build upon the company's fundamental performance. In the long term, investors did not react to sustainability reports. The investors only responded in a short period by enjoying abnormal returns from sustainability reports [28]. Buys [36] stated that economic performance and market performance did not experience significant changes in companies that disclosed sustainability reports.

Based on the result it is known that not all companies can improve their company performance. Ameer and Othman [31] state that social responsibility requires funds and it can worsen company performance conditions. Social responsibility may create limitations for the company so that the company's performance gets worse. Investments in social performance can increase demand for goods but this demand will also increase production costs and ultimately lead to lower company performance [37]. Investors and consumers alike can have difficulty knowing which companies are truly committed to sustainability [37,38]. For this reason, companies can create a sustainability reporting framework so that investors can analyze reports and compare them. This is because sustainability reports can be used as a document that legitimizes company behavior [37].

The inability of EVA moderated the effect of sustainability reports on market performance because of the disclosure of sustainability itself could not improve company performance. This result was found by following the researches from Muallifin and Priya [35]. Companies that played an active role 
in environmental preservation spend considerable costs but were unable to improve companies' performance. Stakeholders support and care about social responsibility carried out by the company [39], yet such activities were not profitable in the stock market. Sustainability contributes to companies to earn a good reputation, competitive advantage, and visibility through the market [40,41]. Besides, corporate social responsibility would have a positive impact on company performance, particularly in managing the level of operational efficiency of the company.

\section{Conclusion}

The fundamental performance of companies indexed by SRI KEHATI has not been able to create added value for its shareholders while its market performance has been able to create added value for shareholders. None of the three dimensions of the sustainability report had become a dominant factor because the loading factor was less than 0.5 . Based on the results of data analysis, it is known that sustainability report disclosure is not able to create added value for shareholders. Because the sustainability report did not significantly affect on market performance. The fundamental performance also did not affect on market performance. This result also imply that investors do not aware of fundamental performance in term of economic value added.

\section{References}

[1] Cormier D, Magnan M. The revisited contribution of environmental reporting to investors' valuation of a firm's earnings: an international perspective. Ecol Econ. 2007;62(3):613-26.

[2] Kolk A. Sustainability, accountability and corporate governance: Exploringmultinationals'reporting practices. Bus Strateg Environ. 2008;17(1):1-15.

[3] Papoutsi A, Sodhi MMS. Does disclosure in sustainability reports indicate actual sustainability performance? J Clean Prod [Internet]. 2020;260:121049. Available from: https://doi.org/10.1016/j.jclepro.2020.121049

[4] Santis P, Albuquerque A, Lizarelli F. Do sustainable companies have a better financial performance? A study on Brazilian public companies. J Clean Prod. 2016;133:735-45.

[5] Mahoney L, Thome L, Cecil L, LaGore W. A research note on standalone corporate social responsibility reports: Signaling or greenwashing? Crit Perspect Account. 2013;24(4-5):350-9.

[6] Herbohn K, Walker J, Loo HYM. Corporate social responsibility: The link between sustainability disclosure and sustainability performance. Abacus. 2014;50(4):422-59.

[7] Fernandez-Feijoo B, Romero S, Ruiz S. Multilevel Approach to Sustainability Report Assurance Decisions. Aust Account Rev. 2015;25(4):346-58. 
[8] Clarkson PM, Li Y, Richardson GD, Vasvari FP. Revisiting the relation between environmental performance and environmental disclosure: An empirical analysis. Accounting, Organ Soc. 2008;33(4-5):303-27.

[9] Kwon HB, Lee J. Exploring the differential impact of environmental sustainability, operational efficiency, and corporate reputation on market valuation in high-techoriented firms. Int J Prod Econ. 2019;211(December 2018):1-14.

[10] Eccles RG, Ioannou I, Serafeim G. The impact of corporate sustainability on organizational processes and performance. Manage Sci. 2014;60(11):2835-57.

[11] Lee J. A Global Perspective on Green Sustainability, Corporate Reputation, and Technological Strength for Firm Performance Across Countries. J Distrib Sci. 2012;10(8):15-23.

[12] Nidumolu R, Prahalad CK, Rangaswami MR. Why sustainability is now the key driver of innovation. Harv Bus Rev. 2009;87(9):56-64.

[13] Connelly BL, Ketchen DJ, Slater SF. Toward a "theoretical toolbox" for sustainability research in marketing. J Acad Mark Sci. 2011;39(1):86-100.

[14] Lyon TP, Maxwell JW. Greenwash: Corporate environmental disclosure under threat of audit. J Econ Manag Strateg. 2011;20(1):3-41.

[15] Trumpp C, Guenther T. Too little or too much? Exploring U-shaped relationships between corporate environmental performance and corporate financial performance. Bus Strateg Environ. 2017;26(1):49-68.

[16] Gray R. Is accounting for sustainability actually accounting for sustainability... and how would we know? An exploration of narratives of organisations and the planet. Accounting, Organ Soc. 2010;35(1):47-62.

[17] Bebbington J, Unerman J, O’Dwyer B. Sustainability accounting and accountability. Routledge; 2014.

[18] Journeault M, Levant Y, Picard CF. Sustainability performance reporting: A technocratic shadowing and silencing. Crit Perspect Account [Internet]. 2021;74(xxxx):102145. Available from: https://doi.org/10.1016/j.cpa.2019.102145

[19] Brown HS, de Jong M, Levy DL. Building institutions based on information disclosure: lessons from GRI's sustainability reporting. J Clean Prod. 2009;17(6):571-80.

[20] Etzion D, Ferraro F. The role of analogy in the institutionalization of sustainability reporting. Organ Sci. 2010;21(5):1092-107.

[21] Hahn R, Kühnen M. Determinants of sustainability reporting: a review of results, trends, theory, and opportunities in an expanding field of research. J Clean Prod. 2013;59:521.

[22] Ernstberger J, Grüning M. How do firm-and country-level governance mechanisms affect firms' disclosure? J Account Public Policy. 2013;32(3):50-67.

[23] Lackmann J, Ernstberger J, Stich M. Market reactions to increased reliability of sustainability information. J Bus ethics. 2012;107(2):111-28.

[24] Walker K, Wan F. The harm of symbolic actions and green-washing: Corporate actions and communications on environmental performance and their financial implications. J Bus ethics. 2012;109(2):227-42.

[25] Adams CA. The ethical, social and environmental reporting-performance portrayal gap. Accounting, Audit Account J. 2004;

[26] Carnevale C, Mazzuca M. Sustainability report and bank valuation: evidence from E uropean stock markets. Bus Ethics A Eur Rev. 2014;23(1):69-90.

[27] Guidry RP, Patten DM. Market reactions to the first-time issuance of corporate sustainability reports: Evidence that quality matters. Sustain Accounting, Manag Policy 


\section{J. 2010;1(1):33-50,}

[28] Du S, Yu K, Bhattacharya CB, Sen S. The business case for sustainability reporting: Evidence from stock market reactions. J Public Policy Mark. 2017;36(2):313-30.

[29] Nugroho PI, Arjowo IS. The effects of sustainability report disclosure towards financial performance. Int J Bus Manag Stud. 2014;03(03):225-39.

[30] Schaltegger S, Wagner M. Integrative management of sustainability performance, measurement and reporting. Int J Accounting, Audit Perform Eval. 2006;3(1):1-19.

[31] Ameer R, Othman R. Sustainability practices and corporate financial performance: A study based on the top global corporations. J Bus Ethics. 2012;108(1):61-79.

[32] Jensen MC. Value maximization, stakeholder theory, and the corporate objective function. J Appl Corp Financ. 2001;14(3):8-21.

[33] Holm C, Rikhardsson P. Experienced and novice investors: does environmental information influence investment allocation decisions? Eur Account Rev. 2008;17(3):537-57.

[34] Tortella BD, Brusco S. The Economic Value Added (EVA): an analysis of market reaction. Adv Account. 2003;20:265-90.

[35] Muallifin OR, Priyadi MP. Dampak Pengungkapan Sustainability Report Terhadap Kinerja Keuangan dan Kinerja Pasar. J Ilmu dan Ris Akunt. 2016;5(11):1-19.

[36] Buys P, Oberholzer M, Andrikopoulos P. An Investigation of the Economic Performance of Sustainability Reporting Companies Versus Non-reporting Companies: A South African Perspective. J Soc Sci. 2011;29(2):151-8.

[37] Ching HY, Gerab F, Toste TH. The Quality of Sustainability Reports and Corporate Financial Performance: Evidence From Brazilian Listed Companies. SAGE Open. 2017;7(2).

[38] Connelly BL, Ketchen DJ, Slater SF. Toward a "theoretical toolbox" for sustainability research in marketing. J Acad Mark Sci. 2011;39(1):86-100.

[39] Ruf BM, Muralidhar K, Brown RM, Janney JJ, Paul K. An empirical investigation of the relationship between change in corporate social performance and financial performance: A stakeholder theory perspective. J Bus ethics. 2001;32(2):143-56.

[40] Searcy C, Elkhawas D. Corporate sustainability ratings: an investigation into how corporations use the Dow Jones Sustainability Index. J Clean Prod. 2012;35:79-92.

[41] Ates S. Membership of sustainability index in an emerging market: Implications for sustainability. J Clean Prod [Internet]. 2020;250(xxxx):119465. Available from: https://doi.org/10.1016/j.jclepro.2019.119465 